\title{
Practical Research on the Integration of Curriculum Ideology and Politics into the Teaching Reform of Nursing Specialty
}

\author{
Jinxiu Li, Zhengying Chen*, Shiyun Chen \\ Jishou University School of Medicine, Jishou 416000, Hunan Province, China \\ *Corresponding author: Prof. Zhengying Chen, $1927383159 @$ qq.com
}

\begin{abstract}
Curriculum ideology and politics" is a new concept and model of education as well as teaching innovation in colleges and universities. Focusing on the fundamental task of strengthening moral education and cultivating people along with the nursing curriculum, this article analyzes the main problems existing in the "curriculum ideology and politics" in nursing education, takes the nursing course as the starting point, and proposes suggestions for the teaching reform of "curriculum ideology and politics" in nursing education.
\end{abstract}

Keywords: Curriculum ideology and politics; Nursing; Reform in education

Publication date: November 2021; Online publication: November 30, 2021

\section{Introduction}

Colleges and universities are important places to train builders and successors of the socialist cause. "Strengthening moral education and cultivating people" is the foundation of colleges and universities. This concept runs through the whole process of education and teaching [1]. For a long time, colleges and universities in China rely on ideological and political theory courses to carry out ideological and political education, but their roles are limited ${ }^{[2]}$. General Secretary Xi Jinping urged, "Ideological and political theory courses in colleges and universities should be strengthened and improved; other courses should keep a good canal and plant a good responsibility field so that all kinds of courses can go hand in hand with ideological and political courses to create a synergistic effect ${ }^{[3]}$." Medical students are the reserve force, serving human health and life. The quality of medical students directly affects people's health level; hence, the requirements are higher for them in terms of political ideology and professional ethics. Nursing students (student nurse) are an important part of medical students and professionals who directly escort people's health. Integrating curriculum ideology and politics into nursing education and its teaching reform as well as guiding nursing students to build correct ideology, form good medical ethics, establish noble professionalism, and exquisite professional skills should be highly valued by the higher medical education circle. They are the fundamental purposes of cultivating qualified medical talents in medical colleges and universities in the new era.

\section{Main problems}

\subsection{Lack of curriculum ideology and politics awareness among teachers}

Curriculum ideology and politics is a major strategic decision for the teaching reform in colleges and universities in China. It is not only the key link to implement the fundamental task and goal of "strengthening moral education and cultivating people," but also the specific content running through the 
ideological and political work system.

However, some professional course teachers in colleges and universities lack the awareness of curriculum ideology and politics. It is a common believe that a teacher's professional knowledge is the "real skill," while ideological and political education is an optional "false style," thus separating teaching from educating, morality from cultivating, and the imparting of knowledge from value guidance. Relevant survey data have shown that one third of college teachers believe that ideological and moral education is the responsibility of ideological and political teachers as well as counselors, while professional course teachers are responsible to teach skills ${ }^{[4]}$. In addition, there are problems in the teacher evaluation in several colleges and universities. The phenomenon of emphasizing intellectual education over moral education and scientific research over teaching is common in colleges and universities, resulting in teachers spending more time and energy on scientific research rather than on teaching and educating. Cognition determines action. Only when teachers have the consciousness of teaching and educating, then they can implement curriculum ideology and politics; otherwise, it would become an obstacle in the implementation of curriculum ideology and politics. In fact, in order to truly achieve the educational purpose of "three wide education," professional course teachers need to understand the importance of curriculum ideology and politics, find out the positioning of curriculum ideology and politics, and give full play to the educational role of curriculum ideology and politics, so as to cultivate qualified talents needed by the socialist cause.

\subsection{Lack of teachers' ability in ideological and political education}

Curriculum ideology and politics is the key link to promote talent training as well as ideological and political education. Professional course teachers are the key players in the implementation of curriculum ideology and politics. Their teaching ability directly affects the effectiveness of the education. At present, the teaching ability of professional course teachers has become an issue, restricting the ideological and political development of courses ${ }^{[5]}$. The manifestations of this issue include teachers' lack of ability to excavate ideological and political resources. This may be due to the lack of ideological and political literacy among teachers; they do not know "what to excavate" or "how to excavate." In addition, the teaching materials that are used currently are relatively backward. This is not conducive to teachers in helping them to fully excavate the resources of ideological and political education. The second is the limited ability to integrate ideological and political elements into the teaching of professional courses. Medical courses are highly professional, and professional courses are less related to ideological and political education. It is a common believe that these students should be drilled rigorously with medical theory and operational skills. Hence, teachers are worried that the adoption of curriculum ideology and politics in these courses would affect the teaching effect. Medical science curriculum has strong natural attributes. If the coincidence point between these courses and ideological and political education cannot be found and teachers only explain the curriculum content without deeply exploring the ideological and political elements contained in medical curriculum, there would be a separation of form and spirit. The phenomenon of "double-faced" in and out of class can be seen among some teachers, and some teachers even use negative words or act wrongfully, violating ethics, public order, and good customs. All these affect the role of curriculum ideology and politics.

\subsection{Lack of a scientific evaluation system for curriculum ideological and political education}

"Only turbulent water can move like waves; only through encouragement, one would have the courage to struggle." Effective evaluation and motivation can stimulate people's motivation as well as mobilize their enthusiasm and creativity. At present, although colleges and universities attach great importance to the construction of curriculum ideology and politics, they lack a scientific and reasonable evaluation system of curriculum ideology and politics. The advantages and disadvantages of teachers' curriculum ideological 
and political construction have not been fully reflected in assessment and evaluation, professional title evaluation, merit evaluation, reward, talent selection, and so on; hence, it is difficult to create a vigorous atmosphere of curriculum ideological and political construction. Education evaluation is the direction of education development. The evaluation mechanism of curriculum ideological and political teaching is not only an important link in the whole teaching operation, but also a weak link in colleges and universities. The quality evaluation of curriculum ideological and political teaching integrates the comprehensive evaluation of teaching and educating people as well as talent and morality. There are many qualitative components in regard to its teaching effect; thus, there is a difficulty in quantifying it. This in turn leads to the absence, unsound, over-macro, one-sided, or an irrational and unreasonable evaluation system ${ }^{[6]}$. If teachers do not have the guarantee of the system and the encouragement of assessment and evaluation, they would eventually lose enthusiasm; thus, the construction of curriculum ideology and politics cannot be continuously carried out, and it would also be difficult to meet the goal of "strengthening moral education and cultivating people."

\section{Practical exploration of the teaching reform}

\subsection{Strengthening the awareness of teachers in curriculum ideology and politics}

Medical talents trained in colleges and universities should not be "robots," mastering only medical knowledge and skills without any political position or humanistic care. Instead, curriculum ideology and politics should be integrated into the medical curriculum, in order to shape these students into medical professionals with lofty ideals and beliefs, noble medical ethics, as well as rigorous scientific spirit. All the departments in colleges and universities should clearly show the determination of curriculum ideology and politics, change the ideological concepts pertaining to professional course teachers, establish a management system and an assessment system related to curriculum ideology and politics, as well as incorporate the participation and construction results of curriculum ideology and politics into year-end performance assessments. Functional departments should build a platform for curriculum ideological and political education, exemplifying on learning platforms such as Xuexitong and Yiban in resource sharing, so as to improve the effect of ideological and political education as well as highlight the role of curriculum ideology and politics.

Nursing courses should be based on the goal of cultivating qualified successors for the socialist cause. They should not only impart professional nursing knowledge, but also clarify the values of "who to serve" and "how to serve." In terms of value guidance, knowledge imparting, and skills cultivation, teachers of specialized courses should fully explore ideological and political elements, such as ideals and beliefs, political positions, professional ethics, as well as legal concepts, cultivate political discrimination and sensitivity among nursing students, guide students to correctly understand the importance of the specialty, recognize the nobility of saving lives and healing the wounded, as well as cultivate nursing students to develop noble feelings of medical ethics, solid nursing professional knowledge, and exquisite professional skills. For example, in Emergency Nursing, Jishou University School of Medicine combines first aid knowledge and skills with the clinical changes that may occur in COVID-19 patients. Cases of medical personnel who bravely fought in epidemic areas and were of active assistance during the epidemic are used for discussion during lessons to strengthen the sense of professional mission and patriotic responsibility of medical staffs. In Introduction to Nursing, the ideological and political elements in the course are explored in combination with the teaching content, the goal of "strengthening moral education and cultivating people" is taken as the main ideology, and both professional knowledge and ideological education are implemented throughout the whole teaching process. During lessons, knowledge would be imparted, skills would be improved, emotions would be cultivated, and a quality education would be promoted, to help nursing students build a systematic knowledge system, cultivate their patriotism and professional ethics, rescue the 
dying humanitarian spirit, so as to lay a good foundation for training high-quality nursing personnel.

\subsection{Improving teachers' ability in curriculum ideology and politics}

\subsubsection{Excavating ideological and political resources from medical courses}

Courses pertaining to the medical specialty have rich ideological and political resources. Under the premise of following the internal logical system of the course, the ideological and political resources of the nursing course should be excavated, the ideological and political elements in the course should be scientifically developed, and the educational purpose of professional courses as well as ideological and political courses should be realized. The course teachers should carefully study and judge the rationality of resources as well as excavate and refine their spiritual connotation, so as to fully excavate the ideals and beliefs, scientific values, moral feelings, and humanistic spirit contained in the curriculum on the premise of not affecting the logical relationship and knowledge system of professional courses, but in line with the discipline and knowledge logic. According to the talent training plan, Jishou University School of Medicine assumes the teaching and research department as a unit, carefully combs the ideological and political resources of professional courses, deeply excavates the ideological value and spiritual connotation contained in the knowledge system, extracts the contents related to the outlook on life, values, world, family, and country, as well as carries out key demonstration and promotion, covering point by point. Secondly, teachers are encouraged to collect data, summarize experience, and compile teaching materials in the process of curriculum ideological and political construction, as well as to reflect the concept of curriculum ideology and politics in the ordering, updating, and compilation of teaching materials. In addition, it is important to give full play to the auxiliary role of the second classroom. As understood, first classroom is mainly for knowledge transfer, whereas second classroom is for the extension and deepening of knowledge taught. Through the combination of the two, in the process of combining theory and practice, nursing students can improve both their practical and innovation skills, and they can learn to make correct value judgment and value choice.

\subsubsection{Organically integrating ideological and political elements into professional curriculum teaching}

"Good ideological and political work should be like salt. However, it is not possible to just eat salt. The best way is to dissolve salt into various foods and absorb it naturally ${ }^{[6]}$." Ideological and political education organically integrates the elements of ideology and politics into the teaching of professional courses, alike salt. With regard to nursing education, it is necessary to take into consideration of the issues of "how much salt" as well as "when and how to sprinkle" and achieve the merit of educating people in "moistening things silently." Professional courses focus on seeking truth, integrating goodness and beauty into the pursuit of truth, as well as realizing the unity of truth, goodness, and beauty. In the teaching of nursing course, it is important to emphasize on "cooking the big meal" of ideological and political education with appropriate "heat"- language, replace the original boring propaganda and education discourse with a vivid and popular language, as well as use teaching skills and methods loved by students in order to help students realize the meaning of ideological and political education. In view of the curriculum for nursing students, there are different emphases on the ideological and political construction of the curriculum at different levels. For example, for junior nursing students, the curriculum ideological and political construction of public courses and basic medical courses is mainly carried out. The curriculum pays attention to the guidance of students' world outlook, outlook on life, and values, improves basic political quality, and enables students to firmly establish socialist core values. In learning professional core courses, senior nursing students mainly receive strengthening nursing humanistic education and professional values education in order to cultivate their professional spirit and professional ethics. 


\subsubsection{Improving teachers' ability in curriculum ideological and political education}

Teachers are the impetus for curriculum ideology and politics - the organizers and implementers who would realize the goal of "strengthening moral education and cultivating people." Teachers are responsible for "guarding canals and planting fields," and their ability in ideological and political education determines the effect of curriculum ideological and political education. Their ideological attitude, knowledge ability, academic charm, and behavior have subtle impact on the growth of students. Due to the differences between teachers in ideology, cognition, knowledge structure, personality, and other aspects, colleges and universities should strengthen the professional standard of education for teachers through various channels, enhance their moral awareness, improve their moral reasoning, and guide teachers to change the concept of imparting knowledge with value guidance. With the goal of strengthening moral education, cultivating people, guiding ideology, and shaping values, teachers need to be encouraged to consciously learn ideological and political knowledge as well as master ideological and political methods; in addition, they should be advocated to set examples and guide students through both words and deeds, analyze problems with correct knowledge and views, promote ideological and political education from the surface to a deeper aspect, and ensure the perfect combination of teaching and education, so as to reach the commanding height of ideological and political work in colleges and universities. Only when teachers are able to keep a good canal, grow a good responsibility field, and take the initiative to be responsible for educating people, then curriculum ideology and politics can be implemented and bear fruitful results. Jishou University attaches great importance to its curriculum ideological and political work. Firstly, the university has formulated curriculum ideological and political responsibilities and has given full play to the role of grass-roots teaching organizations, such as colleges, departments, teaching and research offices, as well as teaching teams. Moreover, the university has been encouraging teachers to prepare lessons collectively and deeply explore ideological and political elements in the form of special training in addition to specially assigning personnel and professional discussion. Secondly, the university requires the teachers not only to have profound professional knowledge, but also to clarify the social value behind the professional curriculum. Relevant policies have been formulated to assist teachers in carrying out the teaching reform. The university has also been organically integrating moral education into professional knowledge, so there would be ideological and political education in every course. This allows students to grow closer to their teachers, and students would be reassured of the methods used by the teachers, thus realizing the organic unity of truth and teaching.

\section{Conclusion}

Curriculum ideological and political education is the key link for colleges and universities to implement the "three wide education" and develop in an in-depth manner. The learning of professional knowledge has a far-reaching impact on the future career of nursing students. Curriculum ideology and politics can improve the ethical aspect and professionalism of nursing students. Under the guidance of the concept of moral education, Jishou University has made an attempt to reform the ideological and political teaching in nursing courses. Through multiple channels to enhance ideological and political awareness along with various measures to enhance ideological and political capacity as well as establish an evaluation system, Jishou University has deeply explored the ideological and political resources in the nursing course and organically combined value guidance and knowledge. The university assumes professional knowledge as the carrier, organically integrates ideological elements, which is conductive to cultivating high quality nursing talents who are responsible and able to meet the needs of the society, as well as injects new meaning and vitality into abstract and boring medical professional knowledge. Jishou University has made some achievements in carrying out curriculum ideological and political education and improving the comprehensive quality of students. It is an aspiration that the in-depth development of curriculum ideology and politics would follow 
through the theory of "dripping water through a stone and reaping an earth-shaking effect," boost China's nursing education to a higher level, and cultivate medical students of a new era who love their career, respect their lives, and climb the peak of medicine.

\section{Funding}

This study was supported by the Hunan Academic Degree and Graduate Education Reform Research Project (Number: 2020JGYB216), the Hunan Ordinary Colleges and Universities Teaching Reform Research Project (HNJG-2020-0537), and the Teaching Reform Research Project of Hunan Province Ordinary Colleges and Universities of 2018 (Item Number: 398).

\section{Disclosure statement}

The authors declare that there is no conflict of interest.

\section{References}

[1] Ma K, Niu D, Li W, et al., 2020, Research on the Integration of Curriculum Ideology and Politics into Molecular Biology Course Teaching Process. Education Forum, (13).

[2] Liang X, 2018, Some Thoughts on Curriculum Thought and Politics. Education Forum, (30): 42-43.

[3] Xi J, 2017, Xi J: The Governance of China (Volume 2), Foreign Languages Press, Beijing, 377-379.

[4] Zhang D, Hong Y, 2021, Problems and Countermeasures in the Implementation of Curriculum Ideology and Politics. Journal of Liaoning Teachers College (Social Science Edition), (1): 59-60.

[5] Zhu P, 2020, Motivation and Quality Evaluation of Ideological Politics in College Curriculum. Ideological \& Theoretical Education, (10): 25-26.

[6] 2016, Xi Jinping Emphasized the Ideological and Political Work Throughout the Whole Process of Education and Teaching and Opened up a New Prospect for the Development of Higher Education in China. People's Daily. 